\title{
MULTI FORMULATED REGRESSION SLIGHTLY OUTPERFORM BACK PROPAGATION ARTIFICIAL NEURAL NETWORK ON RECOGNISING GAUSSIAN RANDOMIZED TWO DIMENSIONAL DATA AS BLOOD GLUCOSE LEVEL NON INVASIVE MEASUREMENT MODEL
}

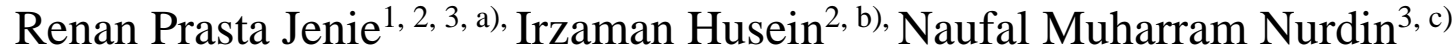 \\ ${ }^{1}$ Child Growth and Development Cohort Study, Sumeru, Bogor 10560 \\ ${ }^{2}$ Department of Physics, Bogor Agricultural University, Dramaga Kode Pos 16680 \\ ${ }^{3}$ Department of Community Nutrition, Bogor Agricultural University, Dramaga Kode Pos 16680 \\ Email: a)qwerty_user1983@outlook.com, b)irzaman@apps.ipb.ac.id, c)naufalmn.ipb@gmail.com
}

\begin{abstract}
Abstrak
Diabetes menyebabkan 1,5 juta kematian pada tahun 2012. Glukosa darah yang lebih tinggi dari pada optimal, sebagai pendahulu diabetes, menyebabkan 2,2 juta kematian tambahan. Pemantauan tingkat glukosa darah penting untuk mengurangi masalah. Ini mengilhami Kelompok Kerja Biomarker Non Invasive menjalankan penelitian untuk mengukur tingkat glukosa darah dengan perilaku non invasif, yang bekerja dengan menggunakan metode berbasis spektrofotometri, dan mesin inferensi yang tepat diperlukan untuk mengenali respons spektral alat. Tujuan penelitian ini adalah untuk membandingkan kinerja (MFR) dan Back Propagation Artificial Neural Network (BPANN). Ini adalah studi eksperimental komparatif. Kami membiarkan kedua mesin inferensi untuk mempelajari data pelatihan buatan yang sama dan mengukur Rooted Means of Squared Error (RMSE). Penelitian dilakukan di Laboratorium Fisika Material, Jurusan Fisika, Institut Pertanian Bogor, pada bulan Januari 2017. BPANN mencapai $16.658 \mathrm{mg}$ / dl RMSE, berlawanan dengan MFR pada $15.295 \mathrm{mg} / \mathrm{dl}$. MFR dapat mengungguli BPANN dalam mempelajari akurasi dan kecepatan eksekusi, dengan mengorbankan waktu pelatihan yang jauh lebih lama. Kami merekomendasikan penggunaan MFR di atas BPANN untuk diujicobakan untuk mengukur data spektral tingkat glukosa darah.
\end{abstract}

Kata-kata kunci: Regulasi Diferensiasi Multi, Propagasi Balik Jaringan Syaraf Tiruan, Alat Pengukuran Tingkat Glukosa Darah Non Invasive, Respons spektral, Pengenalan Pola

\begin{abstract}
Diabetes caused 1.5 million deaths in 2012. Higher-than-optimum blood glucose, as the precursor of diabetes, caused an additional 2.2 million deaths. Blood glucose level monitoring is important to mitigate the problem. This inspiring Non Invasive Biomarking Working Group runs the research to measure blood glucose level in non invasive manners, which works using spectrophotometry based methods, and the proper inference engine is needed to recognize the tools spectral responses. This research objective is to compare performance of Multi Formulated Regression Methods (MFR) and Back Propagation Artificial Neural Network (BPANN). This is a comparative experimental study. We let both inference engines to learn same training data and measure its Rooted Means of Squared Error
\end{abstract}


(RMSE). Research done in Material Physics Laboratory, Department of Physics, Bogor Agricultural University, in January 2017. BPANN achieve $6.1372 \mathrm{mg}$ / dl RMSE, as opposed to MFR at $6.0668 \mathrm{mg} /$ dl. The MFR can outperform BPANN in learning accuracy and execution speed, at the expense of far longer training time. We recommend usage of MFR over BPANN for blood glucose level spectral data.

Keywords: Multi Formulated Regression, Back Propagation Artificial Neural Network, Non Invasive Blood Glucose Level Measurement Tools, Spectral Responses, Pattern Recognition

\section{INTRODUCTION}

Diabetes caused 1.5 million deaths in 2012. Higher-than-optimum blood glucose, as the precursor of diabetes, caused an additional 2.2 million deaths [1]. Blood glucose level monitoring is important to mitigate the problem. This inspiring Non Invasive Biomarking Working Group run the research to measure blood glucose level in non invasive manners, which works using spectrophotometry based methods. And several known spectroscopic methods currently in the research are as described in [2], [3], such as Amplitude Modulated Ultrasound with Infrared Technique [4], [5], Dielectric Spectroscopy [6], Electrical Impedance Spectroscopy [7], [8], LASER Reflected Spectral Patterns [9], Near Infra Red [10], and Occlusion Spectroscopy [11].

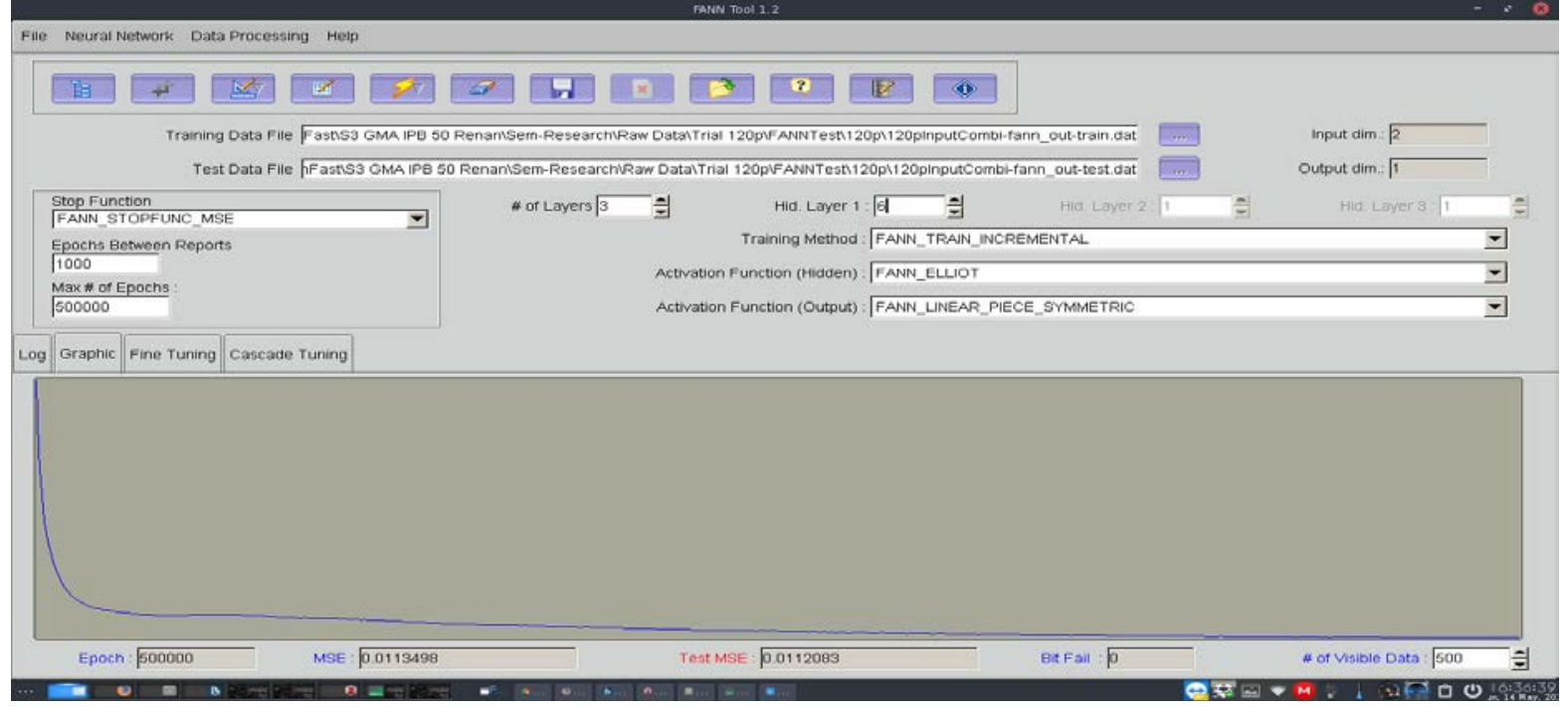

Figure 1. FannTool settings.

Artificial Neural Network long known as a good inference engine to mine raw data, in which we have a set of weighted calculation or activation function nodes that update it weight based on training data [12]. Known training methods include Incremental [13], Batch [14], Reverse / Back Propagation [15], and Quick Propagation [16]. Known activation function includes Linear, Sigmoid, Sigmoid Symmetric, Sigmoid Stepwise, and Sigmoid Symmetric Stepwise [17]. FANN [18] is one of the prominent engine for artificial neural network for $C$ language.

In 2016, James Phillips proposes methods to subsequently curve fit and surface fit set of data using A large collection of equations for Python 3 curve fitting and surface fitting that can output source code in several computing languages, and runs a genetic algorithm for initial parameter estimation, called PYEQ3 [19].

He did not particularly give a name for His methods, so in this manuscript, the authors called it multi formulated regression (MFT).

Whichever method to choose, it results are spectroscopic data that's needed to be inferred to yield measurement data, and the proper inference engine is needed to recognize the device spectral responses. Currently, Performance comparison data between them is not available, as per our 
knowledge. This research compares the accuracy of fit, in rooting means squared error, between FANN and MFT.

\section{METHODS}

This is a comparative study, done in Material Physics Laboratory, Physics Department, Bogor Agricultural University. We create 500 rows of datums consist of 2 input and 1 output, with certified Gaussian random number generator [20] Comparative study done in January 2017. Rooted means squared error (RMSE) used for comparing fitting performance. We use data with 2 input and four output as training and testing data for both methods. Statistical Tools Employed include ALGLIB [21], [22], Zunzun [23], R [24], RKward [25], and epiR [26].

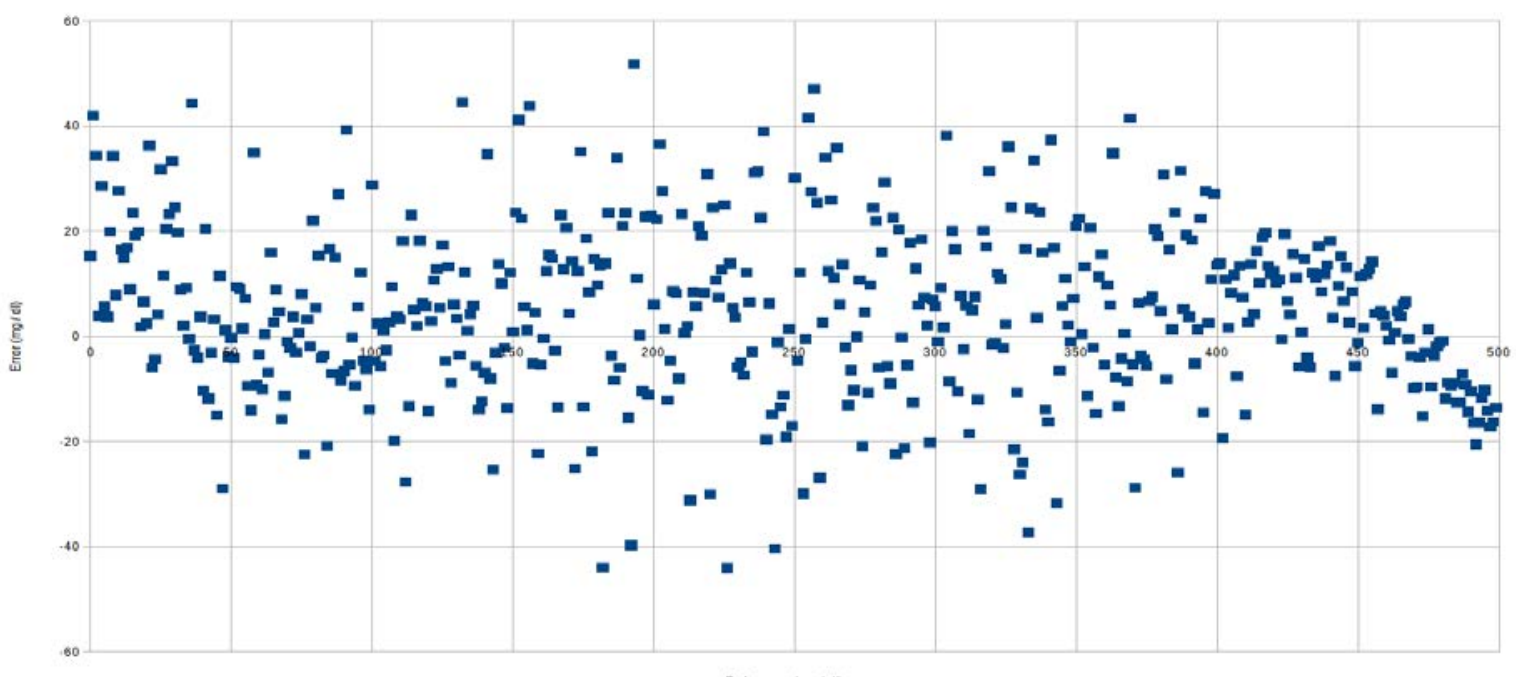

Figure 2. Fann Error Chart.

\section{RESULT AND DISCUSSION}

Computer Terminal Used are one unit of Hewlett Packard Laptop, 4 * AMD A8-6410 APU with AMD Radeon R5 Graphics [27], with 6.8 GiB of RAM, with Bodhi Linux 16.04 [28] installed.

FannTool [29] sets at3 Layers in 2-6-1 format, yields Incremental Training, Elliot Hidden Activation Function and Linear Piece Symmetric Output Activation Function as best settings (Figure 1). Using 500000 Epoch, The lowest RMSE is $15.295 \mathrm{mg} / \mathrm{dl}$ (Figure 2).

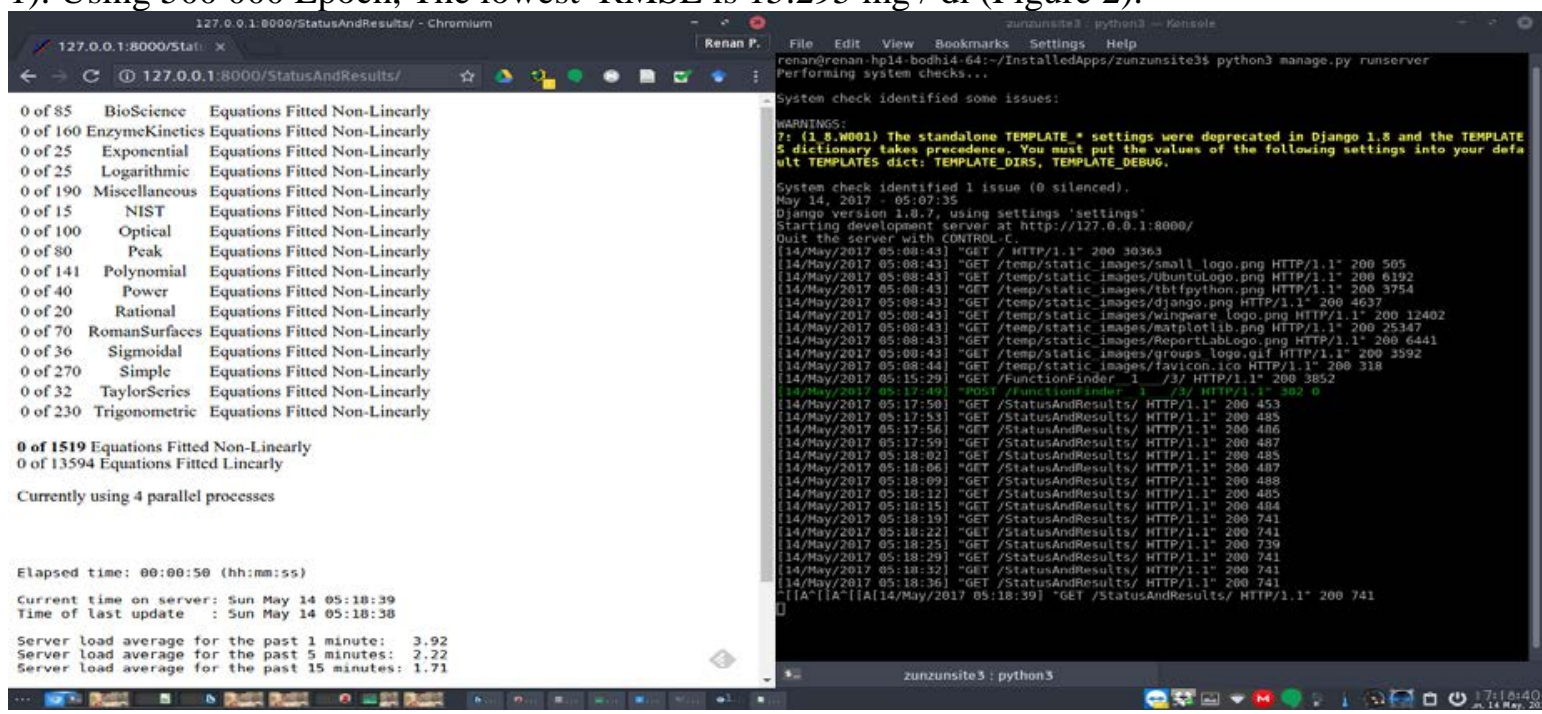

Figure 3. Zunzuntest Settings. 
Zunzuntest [23] set at maximum settings, in which all 1519 equations is non linearly fitted, and 13 594 equations are linearly fitted (Figure 3). The solution gives Gaussian B with Offset equations as best result, with RMSE $15.294 \mathrm{mg}$ / dl (Figure 4).

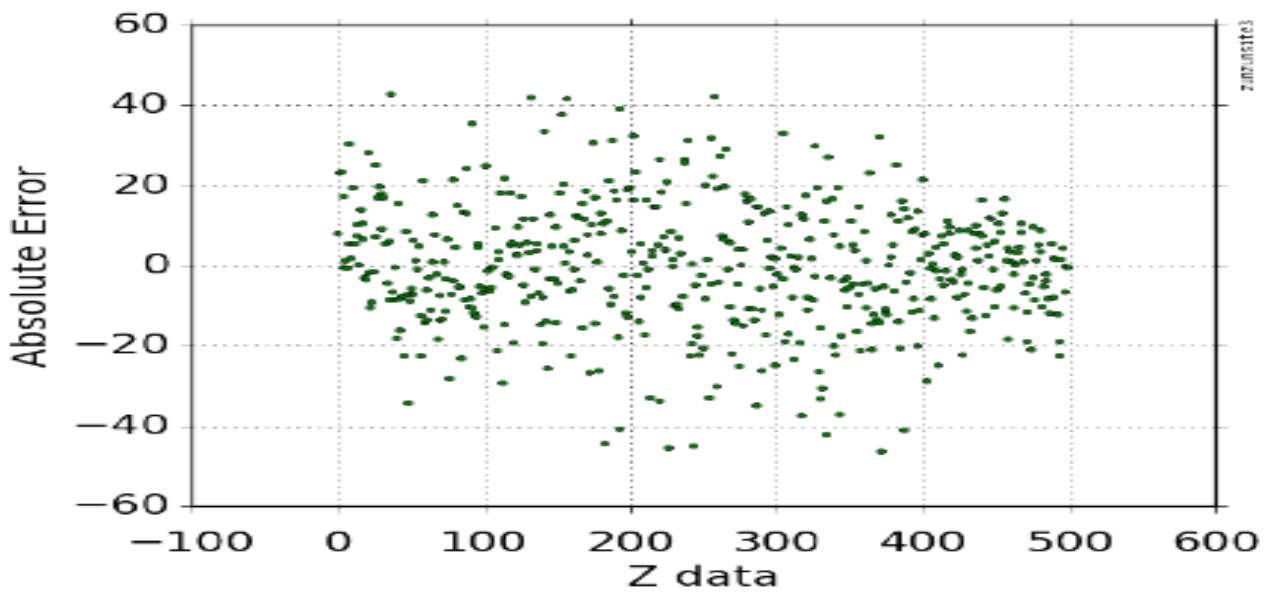

Figure 4. Zunzuntest error chart.

Multi Formulated Regression Slightly Outperform Back Propagation Artificial Neural Network on Recognizing Non Invasive Blood Glucose Level Measurement Tools Spectral Responses, at the cost of far longer training time. The result arguably belong to lighter mathematical formulation, means better performance in real life setting compared to ANN.

Note that, we test the data which the correlation already known, so the result becomes a matter of accuracy. Due to time constraint, we did not test further heavier form of ANN, such as 4 or 5 layered one

\section{ACKNOWLEDGEMENT}

This works supported by IPTEK 2015 no 079/SP2H/LT/DRPM/II/2016, from Negara Kesatuan Republik Indonesia.

We would like to thanks Non Invasive Bio-marking Working Group, Bogor Agricultural University for Their indispensable support for this research.

\section{REFERENCES}

[1] G. Roglic and World Health Organization, Eds., Global report on diabetes. Geneva, Switzerland: World Health Organization, 2016.

[2] S. S. Abdulhalim I, 'Spectral Interrogation based SPR Sensor for Blood Glucose Detection with Improved Sensitivity and Stability’, J. Biosens. Bioelectron., vol. 06, no. 02, 2015.

[3] A. Govada, C. Renumadhavi, and K. B. Ramesh, 'Non-Invasive Blood Glucose Measurement', 2014.

[4] A. Srivastava, M. K. Chowdhury, S. Sharma, and N. Sharma, 'Measurement of Glucose Concentration using Amplitude Modulated Ultrasound with Infrared Technique in Intralipid Phantoms and Human Whole Blood Mixed Intralipid Phantoms of Healthy and Diabetic Subjects’, Biosci. Biotechnol. Res. Asia, vol. 11, no. 2, pp. 593-602, Sep. 2014.

[5] M. K. Chowdhury, A. Srivastava, N. Sharma, and S. Sharma, 'The Role of Amplitude Modulated Ultrasonic Standing Waves and Infrared Light in Noninvasive detection of Blood Glucose Levels’, Adv. Bioresearch, 2014. 
[6] G. Gelao, R. Marani, V. Carriero, and A. G. Perri, 'Design of a dielectric spectroscopy sensor for continuous and non-invasive blood glucose monitoring', Int. J. Adv. Eng. Technol., vol. 3, no. 2, pp. 55-64, 2012.

[7] Q. D. Hossain and S. K. Dhar, 'Characterization of Characterization of Physiological Physiological Physiological Glucose Concentration cose Concentration cose Concentration Using Electrical Impedance Spectroscopy Electrical Impedance Spectroscopy', Int. J. Comput. Sci. Issues, 2013.

[8] S. Sbrignadello, A. Tura, and P. Ravazzani, 'Electroimpedance Spectroscopy for the Measurement of the Dielectric Properties of Sodium Chloride Solutions at Different Glucose Concentrations', J. Spectrosc., vol. 2013, pp. 1-6, 2013.

[9] P. Singh, H. Kaur, and K. V. P. Singh, 'Non-invasive Blood Glucose Level Measurement from LASER Reflected Spectral Patterns Images’, 2013.

[10] A. Srivastava, M. K. Chowdhury, S. Sharma, and N. Sharma, 'Optical Clearance Effect Determination of Glucose by near Infrared Technique: An Experimental Study using An Intralipid Based Tissue Phantom', Int. J. Adv. Eng. Technol. IJAET, vol. 6, no. 3, pp. 10971108, 2013.

[11] A. A. Shinde and R. K. Prasad, 'Non Invasive Blood Glucose Measurement using NIR technique based on occlusion spectroscopy', Int. J. Eng. Sci. Technol. IJEST, vol. 3, no. 12, 2011.

[12] R. Parveen, M. Nabi, F. A. Memon, S. Zaman, and M. Ali, 'A review and survey of artificial neural network in medical science’, J Adv Res Comput Appl, vol. 3, no. 1, pp. 8-17, 2016.

[13] P. Malik, S. Singh, and B. Arora, 'An Effective Weather Forecasting Using Neural Network’, Int. J. Emerg. Eng. Res. Technol., vol. 2, no. 2, pp. 209-212, 2014.

[14] N. Z. Zacharis, 'Predicting Student Academic Performance in Blended Learning Using Artificial Neural Networks’, Int. J. Artif. Intell. Appl., vol. 7, no. 5, pp. 17-29, Sep. 2016.

[15] S. S. Dahikar and S. V. Rode, 'Agricultural crop yield prediction using artificial neural network approach’, Int. J. Innov. Res. Electr. Electron. Instrum. Control Eng., vol. 2, no. 1, pp. 683-686, 2014.

[16] H.-C. Huang, 'The construction of a Visitor number forecasting model for the Shihmen Reservoir recreation area using artificial intelligence technology', J. Theor. Appl. Inf. Technol., vol. 54, no. 1, pp. 14-19, 2013.

[17] P. Sibi, S. A. Jones, and P. Siddarth, 'Analysis of different activation functions using back propagation neural networks’, J. Theor. Appl. Inf. Technol., vol. 47, no. 3, pp. 1264-1268, 2013.

[18] FANN, 'Fast Artificial Neural Network Library (FANN)', 2015. [Online]. Available: http://leenissen.dk/fann/wp/. [Accessed: 25-Dec-2015].

[19] J. Phillips, pyeq3: A large collection of equations for Python 3 curve fitting and surface fitting that can output source code in several computing languages, and run a genetic algorithm for initial parameter .. 2017.

[20] RANDOM.ORG, 'RANDOM.ORG - Gaussian Random Number Generator’, 2017. [Online]. Available: https://www.random.org/gaussian-distributions/. [Accessed: 28-May-2017].

[21] ALGLIB Project, 'ALGLIB', 2017. [Online]. Available: http://www.alglib.net/. [Accessed: 01-Feb-2017].

[22] E. Muñoz and C. Seijas, 'Análisis Comparativo de Ajuste en Entrenamiento de Redes Neuronales artificiales a partir de las Librerías Open NN y ALGLIB’, La Granja, vol. 21, no. 1, Jun. 2015. 
[23] J. Phillips, zunzunsite3: A Django site in Python 3 for curve fitting 2D and 3D data that can output source code in several computing languages and run a genetic algorithm for initial parameter estimation. Inc.. 2017.

[24] Y. Dixit, R. Cama, C. Sullivan, L. Alvarez Jubete, and A. Ktenioudaki, 'Near infrared hyperspectral image analysis using R. Part 5: Animated visualisation of hyperspectral data using R and ImageJ', NIR News, vol. 25, no. 7, p. 15, 2014.

[25] S. Rödiger, T. Friedrichsmeier, P. Kapat, M. Michalke, and others, 'RKWard: a comprehensive graphical user interface and integrated development environment for statistical analysis with R', J. Stat. Softw., vol. 49, no. 9, pp. 1-34, 2012.

[26] M. Stevenson et al., 'epiR: An R package for the analysis of epidemiological data', $R$ Package Version 09-43, 2012.

[27] P. Dukan, A. Kovari, and J. Katona, 'Low consumption and high performance intel, AMD and ARM based Mini PCs', in Computational Intelligence and Informatics (CINTI), 2014 IEEE 15th International Symposium on, 2014, pp. 127-131.

[28] Bodhi Linux, 'Welcome’, Bodhi Linux, 10-Aug-2014. .

[29] P. Chanthini and K. Shyamala, 'A Survey on Parallelization of Neural Network using MPI and Open MP', Indian J. Sci. Technol., vol. 9, no. 19, May 2016. 